\section{Accelerated aging for evaluation of vigor in Brachiaria brizantha 'Xaraés' seeds ${ }^{1}$}

\author{
Ariadne Morbeck Santos Oliveira ${ }^{1 *}$ (D), Marcela Carlota Nery ${ }^{2}$ iD, Karina \\ Guimarães Ribeiro ${ }^{3}$ iD, Adriana Souza Rocha ${ }^{2}$ iD, Priscila Torres Cunha ${ }^{2}$
}

ABSTRACT: The aim of this study was to adjust the accelerated aging test to evaluate the physiological potential of seed lots of Brachiaria brizantha 'Xaraés', represented by four lots. Seeds were tested by traditional accelerated aging and with saturated $\mathrm{NaCl}$ solution in five aging periods: $0,24,48,72$ and 96 hours. The profile of the lots was determined by the following measures: moisture content, germination test, first germination count, germination speed index, initial stand, emergence, and emergence speed index. The accelerated aging test makes it possible to separate the lots by the method of saturated $\mathrm{NaCl}$ solution for 24 hours and it is appropriate for evaluation of seed physiological potential.

Index terms: physiological quality, accelerated aging, vigor.

\section{Envelhecimento acelerado para avaliação do vigor de sementes de Brachiaria brizantha cv Xaraés}

RESUMO: Objetivou-se, com esse estudo, adequar o teste de envelhecimento acelerado, para avaliar o potencial fisiológico de lotes de sementes de Brachiaria brizantha cv Xaraés representada por quatro lotes. As sementes foram submetidas ao envelhecimento acelerado tradicional e com solução saturada de $\mathrm{NaCl}$, em cinco períodos de envelhecimento, $0,24,48$, 72 e 96 horas. Para caracterização dos lotes, foram determinados o grau de umidade, o teste de germinação, primeira contagem da germinação, índice de velocidade de germinação, estande inicial, emergência e índice de velocidade de emergência. Conclui-se que o teste de envelhecimento acelerado possibilita a separação dos lotes pelo método com solução saturada de $\mathrm{NaCl}$ por 24 horas, sendo apropriado para a avaliação do potencial fisiológico das sementes.

Termos para indexação: qualidade fisiológica, envelhecimento acelerado, vigor.
Journal of Seed Science, v.42, e202042006, 2020

http://dx.doi.org/10.1590/2317$1545 v 42216691$
E-mail: ariadneoliveira86@gmail.

com

Received: $11 / 20 / 2018$. Accepted: 10/16/2019.

${ }^{1}$ Universidade Federal de Lavras (UFLA), 37200-000 - Lavras, MG, Brasil.

${ }^{2}$ Universidade Federal dos Vales do Jequitinhonha e Mucuri (UFVJM), 39100-000 - Diamantina, MG, Brasil.

${ }^{3}$ Universidade Federal de Viçosa (UFV), 36570-900 - Viçosa, MG, Brasil. 


\section{INTRODUCTION}

There are approximately 47 million hectares of natural pasture and 112 million hectares of planted pasture in Brazil. This total area of pasture is nearly three times greater than that used for grain production, which currently exceeds 56 million hectares (IBGE, 2018). Establishment and growth of pastures can occur through vegetative processes or, in the case of large properties with a high level of technology, through seeds. Thus, seed quality is fundamental for obtaining an adequate and uniform stand (Costa et al., 2011).

For evaluation of this quality, the germination test is the official procedure that evaluates the capacity of seeds to produce normal seedlings under ideal conditions. Nevertheless, this test does not always reveal differences of performance between seed lots during storage or in the field (Carvalho and Nakagawa, 2012). Thus, it is important to evaluate seed vigor to complement the information provided by the germination test.

Among the vigor tests developed, accelerated aging is one of the most studied for various species grown, and it is used in diverse quality control programs adopted in seed companies by exhibiting efficiency in comparison of vigor and in estimation of the storage potential of the seed lots. The accelerated aging test has shown a good relationship to the seedling emergence test in the field (Marcos-Filho, 2015a).

Initially developed for the purpose of estimating the longevity of stored seeds (Delouche and Baskin, 1973), accelerated aging has been widely studied with the aim of standardizing it, for its use is quite promising. In this test, the seeds are subjected to simulated stress conditions through high temperatures and high relative humidity (100\%), generating high respiration rates and consumption of seed reserves, causing degenerative changes in seed metabolism and changes in the antioxidant defense system and in the soluble sugar content in the embryo (Bijanzadeh et al., 2016; Barreto and Garcia, 2017; Moncaleano-Escandon et al., 2013; Das and Roychoudhury, 2014; Lehner et al., 2008). Thus, more vigorous seeds better tolerate this aging condition than those of lower vigor and produce a higher percentage of normal seedlings, evaluated by the germination test after aging (Baalbaki et al., 2009; Marcos-Filho, 2015b; Pereira et al., 2012; Silva et al., 2010; Moraes et al., 2016).

Yet accelerated aging with water, which leads to relative humidity of $100 \%$, can cause accentuated variations among the moisture contents of the samples, interfering in the results of the test. Thus, Jianhua and McDonald (1996) aimed to reduce the relative humidity during the test and proposed the use of a saturated $\mathrm{NaCl}$ saline solution, which leads to relative humidity of $76 \%$, causing moderate aging, similar to the "natural aging" of the seeds, in contrast with the traditional procedure.

Although the accelerated aging test has been widely studied for different species, the information available from it, aiming at evaluation of the vigor of forage seeds, is old or quite scarce. Accelerated aging at 43 o $\mathrm{C}$ for $48 \mathrm{~h}$ was used by Dias et al. (2004) to monitor the physiological quality of Brachiaria brizantha cv Marandu seeds during storage. CavalcanteFilho and Usberti (2008) used accelerated aging to break the dormancy of B. brizantha cv Marandu seeds and Mulato 1 and Mulato 2 hybrids. These authors concluded that the temperature of $43^{\circ} \mathrm{C}$ for $72 \mathrm{~h}$ was effective in breaking dormancy. Usberti (1990) used accelerated aging to estimate storage of $B$. decumbens seeds and observed its effectiveness when conducted at $43 \stackrel{\circ}{\circ}$ and $100 \%$ RH for 36 and sixty hours.

In this context, the aim of this study was to adjust the method of the accelerated aging test to evaluate the physiological quality of Brachiaria brizantha cv Xaraés seeds.

\section{MATERIAL AND METHODS}

The study was conducted in the Seed Analysis Laboratory of the Universidade Federal dos Vales do Jequitinhonha e Mucuri (UFVJM) in the city of Diamantina, MG. Four lots of Brachiaria brizantha cv. Xaraés seeds were used, which were evaluated regarding physiological quality through the following determinations and tests:

Moisture content: this was determined by the laboratory oven method at 105 ㅇ C for 24 hours (Brasil, 2009).

Germination test: four replications of fifty seeds per lot, distributed on two sheets of blotting paper moistened with distilled 
water in the amount of 2.5 times the weight of the substrate, were placed in a plastic box and then in a B.O.D. type germinator at a temperature alternating between $20 \stackrel{\circ}{\circ}-35 \stackrel{\circ}{\circ}$ with constant lighting. Evaluations began at seven days (first germination count) and ended at 21 days after setting up the trials, based on the criteria recommended in Brasil (2009). The germination speed index (GSI) was performed together with the germination test, counting the number of germinated seeds daily until stabilization; calculations were made according to the formula of Maguire (1962).

Seedling emergence test: four replications of fifty seeds were sown at $1 \mathrm{~cm}$ depth in a soil and sand substrate (1:2) in plastic trays. Moisture of the substrate was adjusted to $60 \%$ of water holding capacity. When emergence began, daily evaluations were made, computing the initial stand on the $7^{\text {th }}$ day and the number of emerged seedlings until stabilization. The emergence speed index (ESI) was determined according to the formula of Maguire (1962).

Accelerated aging (traditional procedure): two hundred seeds were placed on a metal screen in a plastic box containing $40 \mathrm{~mL}$ of distilled water at the bottom. The plastic boxes were placed in a B.O.D. type germination chamber for $24,48,72$ and 96 hours, at the temperature of $45^{\circ} \mathrm{C}$. After passing through each period of accelerated aging, the seeds were placed for germination. The percentage of normal seedlings was evaluated on the $21^{\text {st }}$ day after sowing (Brasil, 2009). Moisture content was also determined after each period of accelerated aging (Brasil, 2009).

Accelerated aging (saturated saline solution): this was conducted as described for the traditional accelerated aging test; however, a saturated sodium chloride $(\mathrm{NaCl})$ solution at the proportion of $40 \mathrm{~g}$ of $\mathrm{NaCl}$ to $100 \mathrm{~mL}$ of water was placed within each plastic box, which leads to relative humidity of $76 \%$ (Jianhua and McDonald, 1996).

A completely randomized experimental design (CRD) was used, with four replications. A $4 \times 5$ factorial arrangement (four seed lots and five accelerated aging periods) was adopted for each method, both the traditional method and the method with saturated $\mathrm{NaCl}$ solution. Analysis of variance was used on the data and the mean values were clustered by the Scott-Knott test at $5 \%$ probability. The result of the accelerated aging test was correlated with those previously described through simple correlation.

\section{RESULTS AND DISCUSSION}

The moisture content of the seed lots evaluated was similar, ranging from $8.34 \%$ to $9.95 \%$, i.e., there was a variation of less than one percentage point (pp) among the lots (Table 1). This indicates that the test was in the recommended range because, according to Marcos-Filho (2015a), the test should be set up with samples whose moisture content does not vary more than two percentage points. Variations in percentage points greater than this impede standardization of any method, as well as impede obtaining uniform results among laboratories or even within the same laboratory.

The tests performed in the laboratory to obtain the initial quality of the seed lots (Table 1) did not stratify the lots, or when stratification occurred, it was only in two levels of quality, indicating similarity among the lots. This occurs because laboratory tests are performed under artificial ideal conditions, and the physiological potential of the seeds may be overestimated, which may limit ranking of the seed lots (Haesbaert et al., 2017).

Table 1. Results of normal seedlings in moisture content (MC), germination (G) (\%), first germination count (FGC) (\%), germination speed index (GSI), emergence (E) (\%), initial stand (IS) (\%) and emergence speed index (ESI), obtained from four lots of Brachiaria brizantha cv Xaraés seeds.

\begin{tabular}{cccccccc}
\hline Lot & MC & G & FGC & GSI & E & IS & ESI \\
\hline 1 & 8.34 & $64 \mathrm{a}$ & $19 \mathrm{~b}$ & $3.25 \mathrm{~b}$ & $53 \mathrm{~b}$ & $25 \mathrm{a}$ & $3.11 \mathrm{~b}$ \\
2 & 8.31 & $70 \mathrm{a}$ & $32 \mathrm{a}$ & $4.23 \mathrm{a}$ & $63 \mathrm{a}$ & $23 \mathrm{a}$ & $3.74 \mathrm{a}$ \\
3 & 9.95 & $64 \mathrm{a}$ & $13 \mathrm{~b}$ & $3.25 \mathrm{~b}$ & $43 \mathrm{c}$ & $18 \mathrm{~b}$ & $2.53 \mathrm{c}$ \\
4 & 9.94 & $66 \mathrm{a}$ & $16 \mathrm{~b}$ & $3.54 \mathrm{~b}$ & $31 \mathrm{~d}$ & $14 \mathrm{~b}$ & $1.86 \mathrm{~d}$ \\
\hline $\mathrm{CV}(\%)$ & - & 8.70 & 22.99 & 6.36 & 8.65 & 13.21 & 7.18 \\
\hline
\end{tabular}

Mean values followed by the same lowercase letter in the column do not differ from each other by the Scott-Knott test at $5 \%$ probability. 
In contrast, in the results of the tests related to seedling emergence, significant differences were observed among the lots; in the emergence test and the emergence speed index, the lots were ranked in four levels of quality.

In these results, different responses of the lots were found when they were subjected to the different specific conditions of each test. In this respect, Marcos-Filho (2015a) highlights the need to use various tests to evaluate seed vigor, due to variation in the efficiency of the procedures currently available.

Comparing exposure to traditional accelerated aging and the use of a saturated $\mathrm{NaCl}$ solution (Table 2), it was found that, regardless of the exposure period, the use of a saturated $\mathrm{NaCl}$ solution resulted in moisture contents that were considerably lower and more uniform than those observed for the seeds aged by the traditional procedure.

This occurs because, according to Jianhua and McDonald (1996), in using the saturated $\mathrm{NaCl}$ solution, there will be a reduction in relative humidity within the plastic box, and the seed will absorb water at a slower rate, resulting in lower and more uniform moisture contents compared to traditional accelerated aging. This was also observed by Radke et al. (2018) in chia seeds.

In addition, the use of saturated $\mathrm{NaCl}$ solution reduced fungal development during the test, due to restriction in relative humidity in the environment within the plastic boxes, which does not favor proliferation of microorganisms. In addition, it is probable that the salt solution releases chlorine and sodium ions to the medium and these chlorine ions have antifungal activity and contribute to a reduction in proliferation of fungi (Ávila et al., 2006). Various studies using salt solutions as an antifungal agent have proven to be effective in as in inhibition of conidia germination much as and inhibition of mycelium growth (Fallanaj et al., 2013; Youssef and Hussien, 2020). The absence of fungi during the accelerated aging test with saturated $\mathrm{NaCl}$ solution was also observed by Tunes et al. (2011) in ryegrass seeds.

The results of normal seedlings after the traditional accelerated aging test (Table 3 ) show that there was little sensitivity in classification of the lots up to 72 hours of aging, with separation into only two levels of quality.

Only after 96 hours of aging was it possible to observe differentiation of the lots into three levels of quality, such that lot 2 was of higher quality, lots 1 and 3 of intermediate quality, and lot 4 of lower quality.

Nevertheless, in spite of this differentiation, for these periods of accelerated aging of 72 and 96 hours, the decline in germination was drastic, as also observed by Oliveira et al. (2014) in physic nut and by Silva et al. (2017) in rattlepod (Crotalaria).

This may have occurred because, according to Marcos-Filho (2015a), long periods of traditional accelerated aging can bring about drastic conditions, making it difficult to detect significant differences in quality among seed lots. In addition, this reduction in germination may be related to the high moisture content of the seeds after aging, since seeds with a higher moisture content absorb water more rapidly, leading to deterioration, compared to seeds with lower moisture content (Morais and Rossetto, 2013; Tunes et al., 2012). Such a result can be attributed to the stress condition caused by accelerated aging, which triggers various metabolic reactions, producing what are known as reactive oxygen species (ROSs). An increase in production and accumulation of ROSs and their imbalance with antioxidant mechanisms characterize oxidative stress (Kibinza et al., 2011; Mittler, 2017). Various studies have shown the major damage that

Table 2. Moisture content of Brachiaria brizantha cv Xaraés seed lots under testing by traditional accelerated aging and accelerated aging with $\mathrm{NaCl}$ solution for 24, 48, 72 and 96 hours.

\begin{tabular}{|c|c|c|c|c|c|c|c|c|}
\hline \multirow{3}{*}{ Lot } & \multicolumn{8}{|c|}{ Treatments / Aging periods (hours) } \\
\hline & \multicolumn{4}{|c|}{ Traditional } & \multicolumn{4}{|c|}{$\mathrm{NaCl}$} \\
\hline & 24 & 48 & 72 & 96 & 24 & 48 & 72 & 96 \\
\hline 1 & 14.42 & 15.57 & 15.89 & 20.13 & 8.29 & 9.14 & 10.30 & 10.31 \\
\hline 2 & 11.90 & 11.35 & 12.22 & 16.74 & 7.95 & 7.05 & 7.95 & 7.77 \\
\hline 3 & 17.73 & 19.15 & 19.47 & 24.01 & 10.08 & 11.48 & 11.74 & 11.17 \\
\hline 4 & 18.87 & 22.38 & 22.58 & 27.71 & 10.24 & 9.88 & 7.74 & 9.63 \\
\hline
\end{tabular}


deterioration can cause in seeds through oxidative stress, including peroxidation and degradation of membrane lipids, oxidation of proteins, damage to nucleic acids, enzyme inhibition, and, at higher levels, cell death (Ahmad et al., 2012; Jeevan Kumar et al., 2015; Jyoti and Malik, 2013; Mishra et al., 2011).

Through the method that uses saturated $\mathrm{NaCl}$ solution (Table 3), it was possible to distinguish the lots in four levels of quality after only 24 hours - lot 2 had higher quality, followed by lots 1,3 and 4, thus coinciding with the results of emergence and ESI testing (Table 2).

Use of the saturated $\mathrm{NaCl}$ solution led to lower seed deterioration, even after 96 hours of aging. This occurs because the use of this solution reduces the speed of water absorption by seeds, affecting seed vigor in a milder way, thus obtaining less drastic and more uniform results compared to the traditional method. Yet the effectiveness of the test is not diminished.

Consistent results using this procedure for seed vigor evaluation were obtained by Tunes et al. (2013) in parsley seeds, by Lemes et al. (2015) in Bermuda grass, and Radke et al. (2016) in coriander.

The effectiveness of the traditional accelerated aging test or the saturated saline solution test for seed vigor evaluation was also observed through the correlation between the results of the accelerated aging test and the results obtained in evaluation of seed lot quality, especially when correlated with the seedling emergence test (Figure 1). The correlation of data of a vigor test with seedling emergence in the field is crucial for the test to be considered effective, since a vigor test should not only classify lots into different vigor classes, but should also be as near as possible to results of seedling emergence in the field (Marcos-Filho, 2015a; Melo et al., 2017).

Nevertheless, due to wide variation in the moisture content of the samples when using the traditional accelerated aging test, the accuracy of the results was negatively affected, advising against the use of this method for evaluation of seed physiological quality. This same result was observed by Gordin et al. (2015), who evaluated the physiological quality of Guizota abyssinica seeds and did not recommend the use of traditional accelerated aging, even when it stratified the lots in vigor levels or correlated with emergence; the author suggested using the saturated saline solution.

In this respect, from the results observed in this study, it can be said that the method of accelerated aging with saturated $\mathrm{NaCl}$ solution was effective in detecting subtle differences among seed lots with similar germination. Thus, the period of 24 hours of aging with the use of a saturated $\mathrm{NaCl}$ solution proved to be more adequate since it can be performed in a shorter period, a desirable characteristic in a seed vigor test, as this allows energy savings in equipment and provides results in a faster way.

Table 3. Results of normal seedlings (\%) obtained in the germination test by Brachiaria brizantha cv Xaraés seeds under different periods of traditional accelerated aging and accelerated aging with saturated $\mathrm{NaCl}$ solution.

\begin{tabular}{cccccccccc}
\hline & \multicolumn{10}{c}{ Treatments / Aging periods (hours) } \\
\cline { 2 - 10 } Lot & 24 & 48 & 72 & 96 & 24 & 48 & 72 & 96 \\
\cline { 2 - 10 } & $52 \mathrm{~b}$ & $49 \mathrm{a}$ & $37 \mathrm{a}$ & $27 \mathrm{~b}$ & $51 \mathrm{~b}$ & $55 \mathrm{a}$ & $58 \mathrm{a}$ & $40 \mathrm{~b}$ \\
\hline 1 & $63 \mathrm{a}$ & $46 \mathrm{a}$ & $44 \mathrm{a}$ & $45 \mathrm{a}$ & $62 \mathrm{a}$ & $57 \mathrm{a}$ & $58 \mathrm{a}$ & $52 \mathrm{a}$ & $30 \mathrm{c}$ \\
2 & $51 \mathrm{~b}$ & $26 \mathrm{~b}$ & $25 \mathrm{~b}$ & $22 \mathrm{~b}$ & $42 \mathrm{c}$ & $27 \mathrm{~b}$ & $34 \mathrm{~b}$ & $22 \mathrm{c}$ \\
3 & $36 \mathrm{c}$ & $27 \mathrm{~b}$ & $26 \mathrm{~b}$ & $15 \mathrm{c}$ & $31 \mathrm{~d}$ & $21 \mathrm{~b}$ & $18 \mathrm{c}$ & \\
4 & \multicolumn{10}{c}{15.08} & & & 16.07 & &
\end{tabular}

Mean values followed by the same letter in the column do not differ from each other by the Scott-Knott test at $5 \%$ probability. 


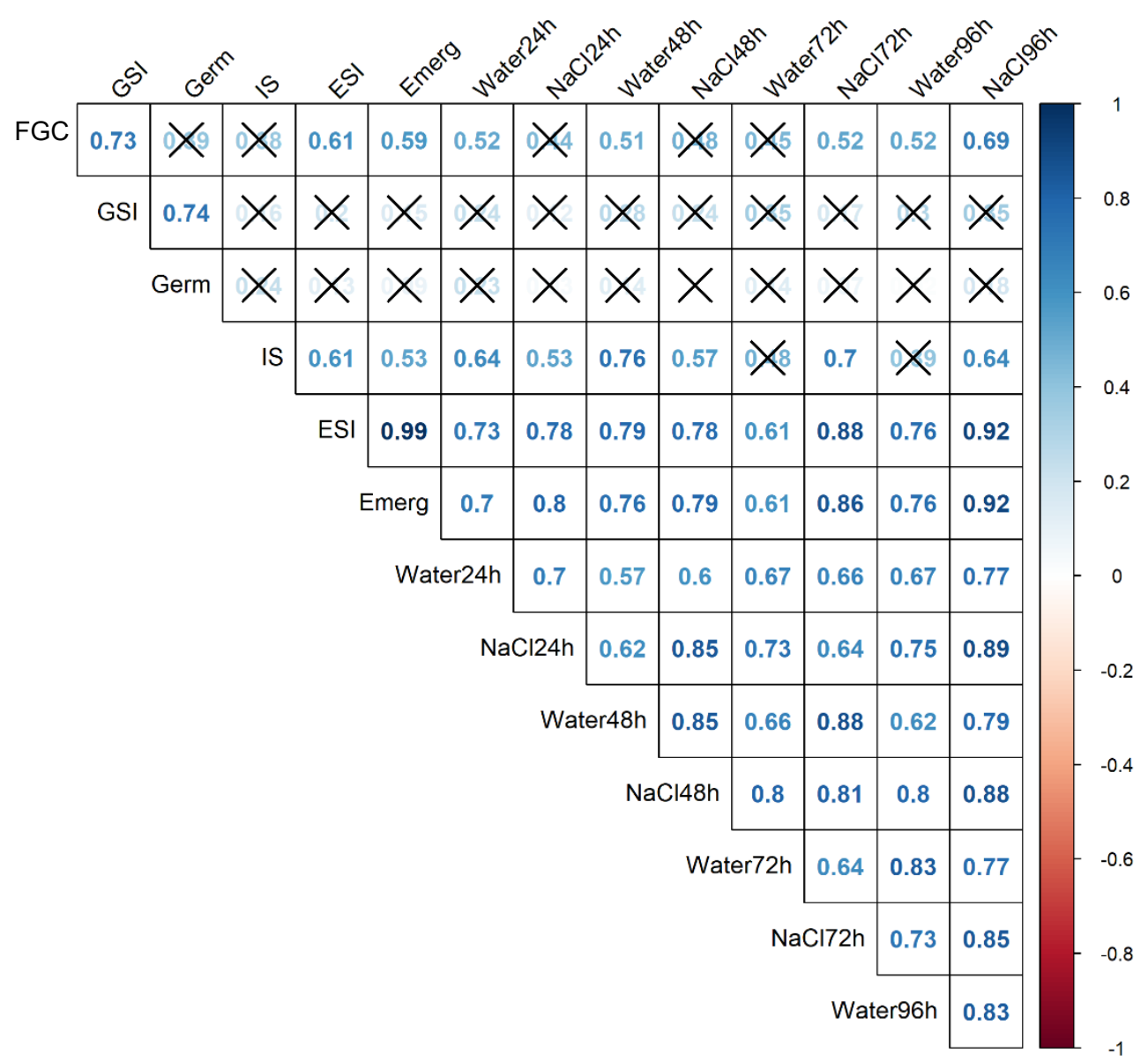

Values marked with an " $X$ " do not have significant correlation at $5 \%$ probability by the t-test.

Figure 1. Simple Pearson correlation ( $r$ ) between the variables of first germination count (FGC), germination speed index (GSI), germination (G), initial stand (IS), emergence speed index (ESI), emergence (E) and the different procedures of the accelerated aging test performed in Brachiaria brizantha cv Xaraés seeds.

\section{CONCLUSIONS}

The accelerated aging test allows separation of $B$. brizantha cv Xaraés seed lots by the method with saturated $\mathrm{NaCl}$ solution for 24 hours.

\section{REFERENCES}

AHMAD, P.; KUMAR, A.; ASHRAF, M.; AKRAM, N.A. Salt-induced changes in photosynthetic activity and oxidative defense system of three cultivars of mustard (Brassica juncea L.). African Journal of Biotechnology, v.11, n.11, p.2694-2703, 2012. https:// academicjournals.org/journal/AJB/article-full-text-pdf/E9AA3E132081

ÁVILA, P.F.V.; VILLELA, F.A.; ÁVILA, M.S.V. Teste de envelhecimento acelerado para avaliação do potencial fisiológico de sementes de rabanete. Revista Brasileira de Sementes, v.28, n.3, p.52-58, 2006. http://www.scielo.br/scielo.php?script=sci_arttext\&pid=S0101$31222006000300008 \& \operatorname{lng}=p t \&$ tlng=pt

BAALBAKI; S.E.; MARCOS-FILHO, J.; McDONALD, M.B. (org.). Seed vigor testing handbook. Ithaca, NY: AOSA, 2009. p.186-200.

BARRETO, L.C.; GARCIA, Q.S. Accelerated ageing and subsequent imbibition affect seed viability and the efficiency of antioxidant system in macaw palm seeds. Acta Physiologiae Plantarum, v.39, n.72, 2017. https://link.springer.com/article/10.1007/s11738017-2367-z 
BIJANZADEH, E.; NADERI, R.; NOSRATI, K.; EGAN, T.P. Effects of accelerated ageing on germination and biochemistry of eight rice cultivars. Journal of Plant Nutrition, v.40, n.2, p.156-164, 2016. https://www.tandfonline.com/doi/full/10.1080/01904167.2016.1201502

BRASIL. Ministério da Agricultura, Pecuária e Abastecimento. Regras para análise de sementes. Ministério da Agricultura, Pecuária e Abastecimento. Secretaria de Defesa Agropecuária. Brasília, DF: MAPA/ACS, 2009. 395p. http://www.agricultura.gov.br/assuntos/ insumos-agropecuarios/arquivos-publicacoes-insumos/2946_regras_analise_sementes.pdf

CARVALHO, N.M.; NAKAGAWA, J. Sementes: ciência, tecnologia e produção. $5^{\text {th }}$ ed. Jaboticabal: FUNEP, 2012.

CAVALCANTE-FILHO, F.N.; USBERTI, R. Thermal and moisture content effects on storability and seed dormancy releasing on Brachiaria brizantha cultivars. Revista Brasileira de Sementes, v.30, n.3, p.95-103, 2008. http://www.scielo.br/scielo.php?script=sci_ arttext\&pid=S0101-31222008000300013

COSTA, C.J.; ARAÚJO, R.B.; VILLAS BÔAS, H.D.C. Tratamentos para a superação de dormência em sementes de Brachiaria humidicola (Rendle) Schweick. Pesquisa Agropecuária Tropical, v.41, n.4, p.519-524, 2011. http://www.revistas.ufg.br/index.php/pat/article/ view/15100

DAS, K.; ROYCHOUDHURY, A. Reactive oxygen species (ROS) and response of antioxidants as ROS-scavengers during environmental stress in plants. Frontiers in Environmental Science, v.2, n.53, 2014. https://www.frontiersin.org/articles/10.3389/fenvs.2014.00053/full

DELOUCHE, J.C.; BASKIN, C.C. Accelerated aging techniques for predicting the relative storability of seed lots. Seed Science and Technology, v.1, p.427-452, 1973. https://ir.library.msstate.edu/bitstream/handle/11668/13316/F-4.pdf?sequence=1\&isAllowed=y

DIAS, D.C.F.S.; SANTOS, P.S.; ALVARENGA, E.M.; CECON, P.R.; ARAÚJO, E.F. Testes para monitorar a qualidade fisiológica de sementes de Brachiaria brizantha (A. Rich.) Stapf. durante o armazenamento. Revista Brasileira de Sementes, v.26, n.2, p.33-44, 2004. https:// dx.doi.org/10.1590/S0101-31222004000200006

FALLANAJ, F.; SANZANI, S.M.; ZAVANELLA, C.; IPPOLITO, A. Salt addition improves the control of citrus postharvest diseases using electrolysis with conductive diamond electrodes. Journal of Plant Pathology, v.95, n.2, p.373-383, 2013. http://www.sipav.org/ main/jpp/index.php/jpp/article/view/2824/1498

GORDIN, C.R.B.; SCALON, S.P.Q.; MASETTO, T.E. Accelerated aging test in niger seeds. Journal of Seed Science, v.37, n.3, p.234-240, 2015. http://www.scielo.br/scielo.php?script=sci_arttext\&pid=S2317-15372015000300234

HAESBAERT, F.M.; LOPES, S.J.; MERTZ, L.M.; LÚCIO, A.D.; HUTH, C. Tamanho de amostra para determinação da condutividade elétrica individual de sementes de girassol. Bragantia, v.76, n.1, p.54-61, 2017. http://www.scielo.br/scielo.php?script=sci_ arttext\&pid=S0006-87052017000100054\&lng=pt\&tlng=pt

IBGE. Ministério do Planejamento, Desenvolvimento e Gestão. Censo agropecuário 2017. Ministério do Planejamento, Desenvolvimento e Gestão. Rio de Janeiro: MP, 2018. 108p.

JYOTI; MALIK, C.P. Seed deterioration: a review. International Journal of Life Sciences Biotechnology and Pharma Research, v.2, n.3, p.374-385, 2013.

JEEVAN KUMAR, S.P.; RAJENDRA PRASAD, S.; BANERJEE, R.; THAMMINENI, C. Seed birth to death: dual functions of reactive oxygen species in seed physiology. Annals of Botany, v.116, n.4, p.663-668, 2015. https://academic.oup.com/aob/article/116/4/663/94197

JIANHUA, Z.; McDONALD, M.B. The saturated salt accelerated aging test for small seeded crops. Seed Science and Technology, v.25, n.1, p.123-131, 1996.

KIBINZA, S.; BAZIN, J.; BAILLY, C.; FARRANT, J.M.; CORBINEAU, F.; EL-MAAROUF-BOUTEAU, H. Catalase is a key enzyme in seed recovery from ageing during priming. Plant Science, v.181, n.3, p.309-315, 2011. https://www.sciencedirect.com/science/article/ pii/S016894521100166X

LEHNER, A.; MAMADOU, N.; POELS, P.; COME, D.; BAILLY, C.; CORBINEAU, F. Changes in soluble carbohydrates, lipid peroxidation and antioxidant enzyme activities in the embryo during ageing in wheat grains. Journal of Cereal Science, v.47, n.3, p.555-565, 2008. https://www.sciencedirect.com/science/article/pii/S0733521007001312

LEMES, E.S.; OLIVEIRA, S.; ALMEIDA, A.S.; MENEGHELLO, G.E.; GEWEHR, E.; TUNES, L.M. Testes de vigor para avaliação da qualidade de sementes de grama-bermuda. Revista de la Facultad de Agronomía, v.114, n.2, p.185-192, 2015. http://sedici.unlp.edu.ar/ bitstream/handle/10915/51294/Documento_completo.pdf-PDFA.pdf?sequence=1 
MAGUIRE, J.D. Speed of germination - aid in selection and evaluation for seedling emergence and vigor. Crop Science, v.2, p.176$177,1962$.

MARCOS-FILHO, J. Seed vigor testing: an overview of the past, present and future perspective. Scientia Agricola, v.72, n.4, p.363374, 2015a. http://www.scielo.br/scielo.php?script=sci_arttext\&pid=S0103-90162015000400363\&lng=en\&tlng=en

MARCOS-FILHO, J. Fisiologia de sementes de plantas cultivadas. $2^{\text {nd }}$ ed. Londrina: ABRATES, 2015b. 660p.

MELO, P.A.F.R.; JEROMINI, T.S.; AFFONSO, C.E.; ALVES, E.U.; MARTINS, C.C. Vigor tests in assessing the quality of signal grass seeds. Semina: Ciências Agrárias, v.38, n.6, p.3491-3498, 2017. http://www.uel.br/revistas/uel/index.php/semagrarias/article/ view/28594/22312

MISHRA, S.; JHA, A.B.; DUBEY, R.S. Arsenite treatment induces oxidative stress, upregulates antioxidant system, and causes phytochelatin synthesis in rice seedlings. Protoplasma, v.248, n.3, p.565-577, 2011. https://link.springer.com/article/10.1007/ s00709-010-0210-0

MITTLER, R. ROS are good. Trends in Plant Science, v.22, n.1, p.11-19, 2017. https://www.sciencedirect.com/science/article/pii/ S1360138516301121

MONCALEANO-ESCANDON, J.; SILVA, B.C.; SILVA, S.R.; GRANJA, J.A.; ALVES, M.C.J.; POMPELLI, M.F. Germination responses of Jatropha curcas L. seeds to storage and aging. Industrial Crops and Products, v.44, p.684-690, 2013. https://www.sciencedirect. com/science/article/pii/S0926669012005092

MORAES, C.E.; LOPES, J.C.; FARIAS, C.C.M.; MACIEL, K.S. Qualidade fisiológica de sementes de Tabernaemontana fuchsiaefolia A. DC em função do teste de envelhecimento acelerado. Ciência Florestal, v.26, n.1, p.213-223, 2016. http://www.scielo.br/scielo. php?script=sci_arttext\&pid=S1980-50982016000100213

MORAIS, C.S.B.; ROSSETTO, C.A.V. Testes de deterioração controlada e envelhecimento acelerado para avaliação do vigor em nabo forrageiro. Revista Ciência Agronômica, v.44, n.4, p.703-713, 2013. http://www.scielo.br/scielo.php?script=sci_ arttext\&pid=S1806-66902013000400006

OLIVEIRA, G.L.; DIAS, L.A.S.; DIAS, D.C.F.S.; SOARES, M.M.; SILVA, L.J. Accelerated ageing test to evaluate vigour in Jatropha curcas L. seeds. Revista Ciência Agronômica, v.45, n.1, p.120-127, 2014. http://www.scielo.br/scielo.php?script=sci_ arttext\&pid=S1806-66902014000100015

PEREIRA, M.D.; MARTINS-FILHO, S.; LAVIOLA, B.G. Envelhecimento acelerado de sementes de pinhão-manso. Pesquisa Agropecuária Tropical, v.42, n.1, p.119-123, 2012. http://www.scielo.br/scielo.php?script=sci_arttext\&pid=S1983-40632012000100017\&lng=pt \&tlng=pt

RADKE, A.K.; REIS, B.B.; GEWEHR, É.; ALMEIDA, A.S.; TUNES, L.M.; VILLELA, F.A. Alternativas metodológicas do teste de envelhecimento acelerado em sementes de coentro. Ciência Rural, v.46, n.1, p.95-99, 2016. http://www.scielo.br/scielo. php?script=sci_arttext\&pid=S0103-84782016000100095\&lng=pt\&tlng=pt

RADKE, A.K.; XAVIER, F.M.; EBERHARDT, P.E.R.; VILLELA, F.A.; MENEGHELLO, G.E. Methodological adjustment of the accelerated aging test to evaluate the vigor of chia seeds. Journal of Seed Science, v.40, n.2, p.173-178, 2018. http://www.scielo.br/scielo. php?script=sci_arttext\&pid=S2317-15372018000200173\&Ing=en\&tlng=en

SILVA, C.B.; BARBOSA, R.M.; VIEIRA, R.D. Accelerated aging as vigor test for sunn hemp seeds. Ciência Rural, v.47, n.1, 2017. http:// www.scielo.br/scielo.php?script=sci_arttext\&pid=S0103-84782017000100402\&lng=en\&tlng=en

SILVA, C.B.; PIVETTA, K.F.L.; OLIVEIRA, C.A.V.M.; RODRIGUES, M.A.; VIEIRA, R.D. Teste de envelhecimento acelerado para avaliação do potencial fisiológico de sementes de grama-bermuda. Revista Brasileira de Sementes, v.32, n.2 p.102-107, 2010. http://www. scielo.br/scielo.php?script=sci_arttext\&pid=S0101-31222010000200012\&lng=en\&nrm=iso\&tlng=pt

TUNES, L.M.; PEDROSO, D.C.; BADINELLI, P.G.; TAVARES, L.C.; RUFINO, C.A.; BARROS, A.C.S.A.; MUNIZ, M.F.B. Envelhecimento acelerado em sementes de azevém com e sem solução salina e saturada. Ciência Rural, v.41, n.1, p.33-37, 2011. http://www.scielo. br/scielo.php?script=sci_arttext\&pid=S0103-84782011000100006\&lng=pt\&tlng=pt

TUNES, L.M.; TAVARES, L.C.; RUFINO, C.A.; BARROS, A.C.S.A.; MUNIZ, M.F.B.; DUARTE, V.B. Envelhecimento acelerado em sementes de brócolis (Brassica oleracea L. var. italica Plenk). Bioscience Journal, v.28, n.2, p.173-179, 2012. http://www.seer.ufu.br/index. php/biosciencejournal/article/view/11636/8475 
TUNES, L.M.; PEDROSO, D.C.; GADOTTI, G.I.; MUNIZ, M.F.B.; BARROS, A.C.S.A.; VILLELA, F.A. Accelerated aging to assess parsley seed vigor. Horticultura Brasileira, v.31, n.3, p.457-460, 2013. http://www.scielo.br/scielo.php?script=sci_arttext\&pid=S010205362013000300018\&lng=en\&tlng=en

USBERTI, R. Determinação do potencial de armazenamento de lotes de sementes de Brachiaria decumbens pelo teste de envelhecimento acelerado. Pesquisa Agropecuária Brasileira, v.25, n.5, p.691-699, 1990. http://seer.sct.embrapa.br/index.php/ pab/article/view/13481/7589

YOUSSEF, K.; HUSSIEN, A. Electrolysed water and salt solutions can reduce green and blue molds while maintain the quality properties of 'Valencia' late oranges. Postharvest Biology and Technology, v.159, 2020. https://www.sciencedirect.com/science/ article/pii/S0925521419307720 use, distribution, and reproduction in any medium, provided the original work is properly cited. 